\title{
ATLANTIS - \\ Lessons Learned from an Educational Network for the Mutual Exchange of Academic Courses in Management Information Systems
}

\author{
Uwe Hoppe \\ University of Osnabrueck \\ Osnabrueck, Germany
}

uwe.hoppe@uos.de

\begin{abstract}
In this paper ATLANTIS is described - a network of actual six German universities exchanging courses in varying blended learning scenarios over the Internet. Basic goals are to broaden study programs at the participating locations in MIS, to decrease the number of different courses a professor has to offer as part of her/his teaching load and to enhance flexibility of students who get the chance to take courses at individual convenient times and locations. ATLANTIS courses are running on a centralized Learning Management System (LMS) (Coates, James, \& Baldwin, 2005) with interfaces to each local LMS of the participating universities. In an initial project of two years the technical infrastructure and E-Learning courses have been developed and an organization has been established. Since then the network is in a state of regular use. The case study focuses on organizational issues and lessons learned in 4 years of development and operation.
\end{abstract}

Keywords: educational networks, MIS, blended-learning

\section{Introduction}

ATLANTIS (Academic Teaching and LeArning NeTwork in Information Systems) is an organizational network of six German universities in Lower Saxony. The partners exchange ELearning courses covering subjects from Management Information Systems (MIS) over the internet. A course offered from one partner can be studied by students from any other university participating in the network. Figure 1 shows a map of Lower Saxony and the six university partners.

ATLANTIS is a regional network. Although in principle the network could be open to partners from other German "Bundeslaender", from other German speaking countries in Europe or, based on courses in English, even from countries all over the world, it is today restricted to Lower

Material published as part of this publication, either on-line or in print, is copyrighted by the Informing Science Institute. Permission to make digital or paper copy of part or all of these works for personal or classroom use is granted without fee provided that the copies are not made or distributed for profit or commercial advantage AND that copies 1) bear this notice in full and 2) give the full citation on the first page. It is permissible to abstract these works so long as credit is given. To copy in all other cases or to republish or to post on a server or to redistribute to lists requires specific permission and payment of a fee. Contact 0HPublisher@InformingScience.org to request redistribution permission.
Saxonian Partners. It actually represents the majority of MIS institutes or departments at Universities in this Bundesland. The fact that ATLANTIS is a regional network is important for two reasons:

- Little distances allow for faceto-face meetings with reasonable transaction costs. The distance between two locations takes not more than 2.5 hours by 


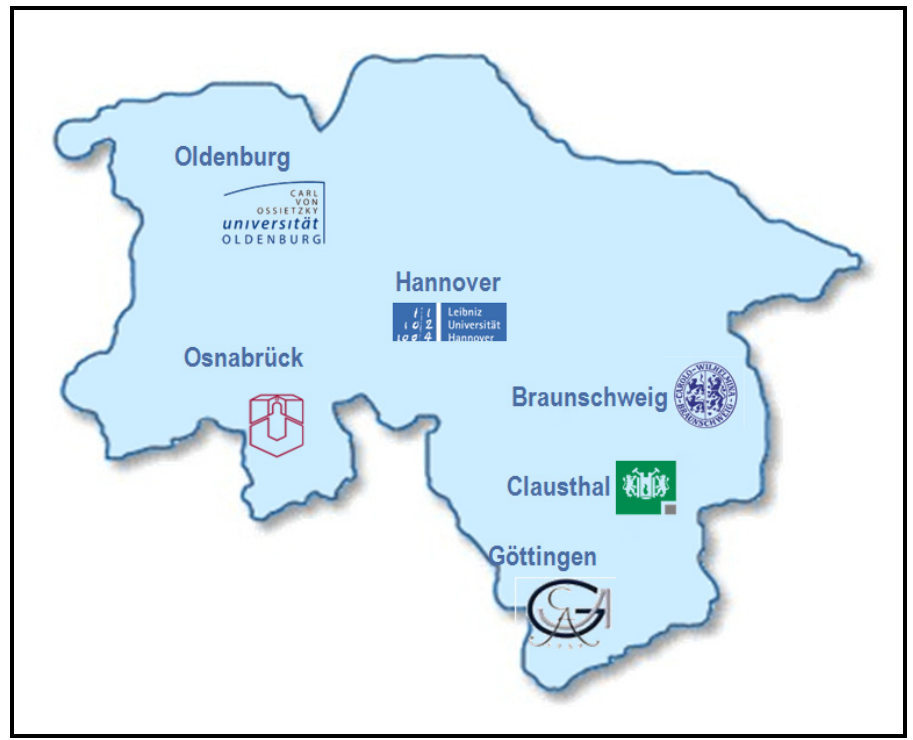

Figure 1: Partner Universities of ATLANTIS

public transportation. No partner has more than 2 hours to go to the central node Hannover.

- University laws and rules in Germany are under the responsibility of the federal governments of the Bundeslaender. Different universities in the same Bundesland therefore share a common legal framework under which research and teaching activities unfold. Nevertheless, these regulations might be amended by rules within the decentralized authority of the universities.

The network was initiated in 2006 for the following reasons:

The problem of "small subjects": in Germany (and most of the other European Countries) the Bologna Process has activated the biggest process of restructuring study programs for decades (Crosier, Purser, \& Smidt, 2007; Rauch \&Teichert 2005). As a result, the former predominating diploma degrees are successively replaced by Bachelor and Master Degrees following the AngloAmerican ideal. As a rule, German MIS programs are oriented to recommendations of the Information Systems section of the German Academic Association for Business Research, VHB (http://pbwi2www.uni-paderborn.de/WWW/VHB/VHB-Online.nsf/id/EN WK WI Start. These recommendations propose a balance of modules and courses in the areas of MIS, Computer Science and Business Administration. MIS Chairs are mostly institutionally situated in business faculties. The number of MIS chairs in a faculty at the same university is mostly between one and three, only rarely you will find more like at the Westfaelische Wilhelms-Universitaet Muenster. So, Bachelor and Master Study programs in MIS are often short of specific capacities in the MIS part. ATLANTIS helps to provide a broad portfolio of MIS courses for study programs in MIS ending with a Bachelor's degree at all the participating universities.

In the last decade, Germany has seen a series of support programs giving grants to research projects in the area of E-Learning. In Lower Saxony, projects have been supported under the roof of the ELAN initiative (http://www.elan-niedersachsen.de/). ATLANTIS has been financed to promote inter-university cooperation in teaching via electronic media. Therefore, ATLANTIS is both a research project and a platform to support academic teaching. External funding ended in 2008. Since then ATLANTIS is maintained by the participating partners, or more exactly, by six MIS chairs. In the following, "chair" is understood as the smallest independent organizational unit below the level of faculties or departments at a university. A chair has a chair holder, usually a pro- 
fessor and as a rule a number of scientific assistants with working contracts which require a mixture of administrative tasks, teaching and self-determined research (in general a dissertation project). Under the term ,university“, I subsume in the following only academic institutions which are allowed to bear the title "Universitaet" in Germany. These universities have to right to offer PhD-programs. Excluded are Universities of Applied Science ("Fachhochschulen"), who are teaching under different conditions in different organizational structures.

It is important to notice the specific legal and cultural framework in which academic teaching at universities unfolds. A professor in Germany has a high degree of independence, compared to the situation in other states. His independence is constitutionally guaranteed by law. The hierarchical power of a dean in a German faculty or of a president for a whole university is limited - compared to other countries, for instance like the United States. As a consequence, decisions often have to be found in consensus, making processes long and tedious. Every German professor has a rather high teaching obligation (see below). But within these quantitative restrictions she or he is more or less free to decide which subjects to offer in lectures and which research projects to apply for. Finally, it is necessary to know that under the euphemistic term "academic self-

administration" over the last decades more and more administrative tasks have been misaligned to academic staff. This - to such an extent - drafted frame will help to understand considerations about benefits and incentives later on in this paper.

In Germany, educational networks which bridge the borders between universities are rare. Another example is Winfoline (Bohl, Frankfurth, Schellhase, \& Winand, 2007; Hagenhof ,2000). In this case study some problems are highlighted which arise if one aspires to cooperation across locations between equal partners in academic teaching.

\section{Technical Architecture}

Figure 2 illustrates the technical infrastructure of ATLANTIS. In the planning phase of the project the following requirements have been stated and later realized:

- Diversity and flexibility of the contents as central part of the blended learning scenarios (see below) which are offered from each partner.

- Single-Sign-On for students and instructors. To sign on into the Learning Management System (LMS) at the respective home university should suffice to get immediate access to the online courses.

- Avoidance of redundancy for all contents: all contents are stored centrally in one LMS. All user data (like names and contact details of students and instructors), communication data (like discussion threads) or course data (like syllabus information, access to online courses, additional downloads) are administrated here.

All participating universities have their own LMS. Fortunately, when the projects started, in five out of six cases it had been the same system called stud.ip (http://www.studip.de/) - an open source based LMS with integrated functions for online learning processes like wikis, media2mult (Gieseking \& Vornberger 2008) and more. Media2mult is a wiki-based authoring system which produces multimedia contents for different formats like html, pdf and more. Unfortunately, all universities had varying versions of this software with different emphasis on functionality and different interfaces to other university systems (like administration systems for grades, enrollment or planning systems for study schedules). Furthermore, some partner universities at that time had more than one LMS running - usually historically grown in different faculties. 


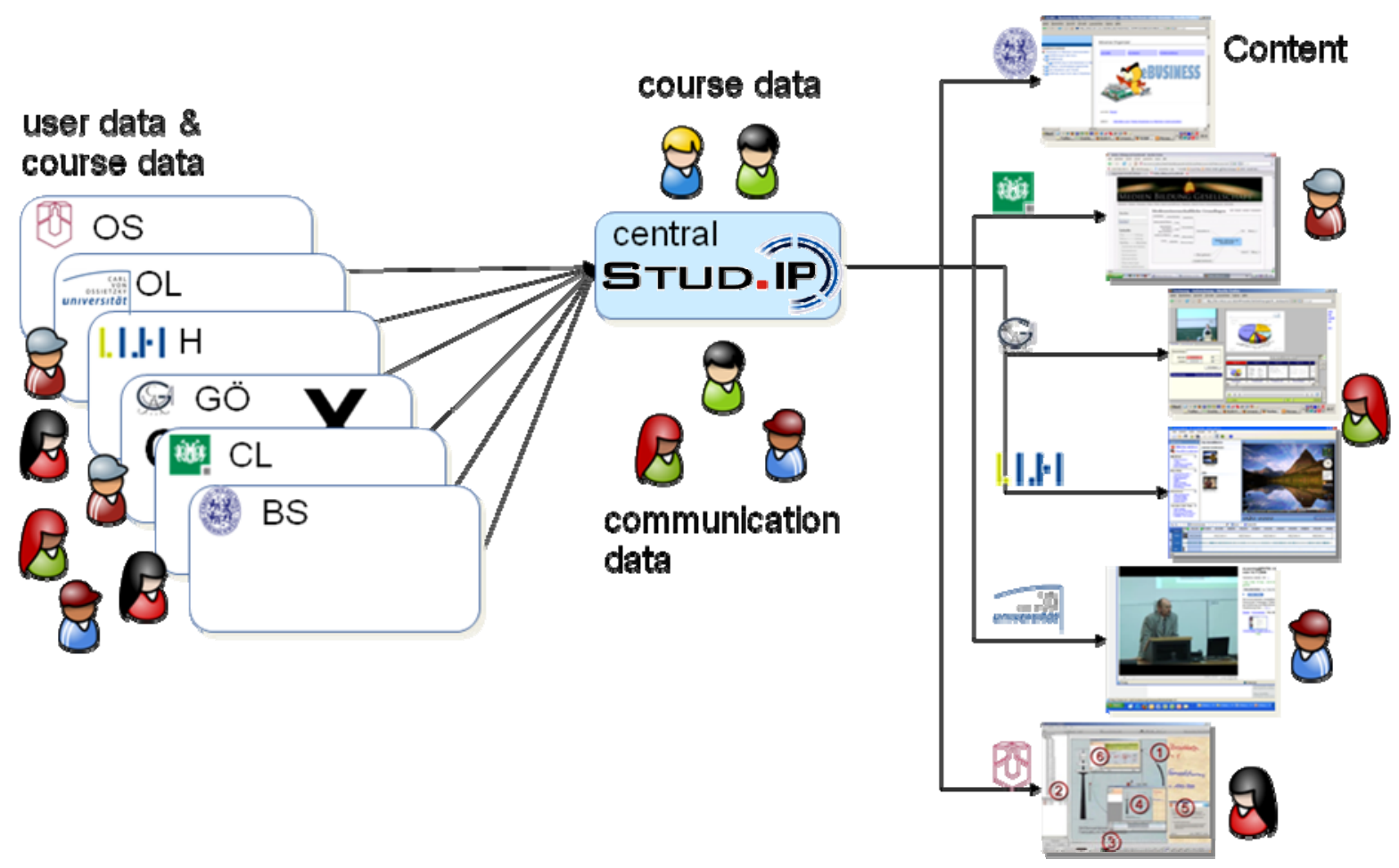

Figure 2: Technical Architecture of ATLANTIS

The technical solution in this situation has been to instantiate a central stud.ip system. Students who are planning their next semester see all available courses in the LMS of their faculty or university. In the same system, all professors or instructors with their contact details are listed, as well as those of fellow students. All ATLANTIS courses are listed in all decentralized LMS of the partners. Typical information compasses those details which are included in a university syllabus. With a click on the provided link a student can change without further authorization to the central LMS. Here, all contents can be studied; all materials can be downloaded. The students are encouraged to place their questions in the discussion boards of the central LMS to make sure that all students attending the same course can read them. Each course description in the central LMS contains an entry link to a Web-based Training or a recorded lecture. Following this click opens a standardized browser window in which the course contents are presented.

\section{Courses and Modules}

At the beginning of the project, each partner has undertaken to provide the following offerings:

- A course for a Bachelor study program in MIS with a scope of five points ECTS (European Credit Transfer System) in average.

- A so called module with a scope of approximately 6 working hours for an introductory course to MIS, often delivered in the first semesters of a program in MIS.

Teaching load for a professor in Lower Saxony (and in most of the other Bundeslaender in Germany) is four courses, each two hours of lecture time per week. Usually, there are 15 weeks in a semester. For a whole year, this sums up to eight different courses per professor. MIS chairs in Germany have between 2 and 4 regularly employed scientific assistants who might be compared to an instructor at an US university. "Regular" means that there are in general more assistants, paid from external grants, who do not have teaching obligations in their working contracts. These assistants have in average half of the teaching load of a professor. So, even for a small chair with 
two assistants, a chair holder is responsible for a considerable number of different courses which have to be delivered over a year. Therefore the ATLANTIS partners had a choice of which course they would open to the network and to students at other participating universities. They decided according to a set of rules of thumb and requirements. A basic requirement for the whole project was to support Bachelor programs. So the course of choice served MIS students between their first and sixth semester. Some of the participating chairs already had a long history of activities in the area of E-Learning. At two chairs, there were already E-Learning modules in daily use. It was a natural choice to take advantage of reusing these courses. They have been amended with actual developments where needed and reworked to fit to the technical requirements of the ATLANTIS architecture. Those chairs which had not already existing courses had to develop them in the first year of the project. The subjects were chosen out of the portfolio of existing (so far non- ELearning) courses in consensus with the other partners who expressed their interest in particular subjects in order to complement their own course program for their Bachelor students. Table 1 shows the results of this decision process.

Table 1: Courses and Modules in the ATLANTIS network

\begin{tabular}{|l|l|l|}
\hline Partner & Course & Modules \\
\hline $\begin{array}{l}\text { TU Carolo-Wihe lmina zu } \\
\text { Braunschweig }\end{array}$ & Business Intelligence & $\begin{array}{l}\text { Conceptual Modeling of } \\
\text { Information Systems (case study: } \\
\text { Car-Sharing-Applications) }\end{array}$ \\
\hline $\begin{array}{l}\text { Technical University } \\
\text { Clausthal }\end{array}$ & $\begin{array}{l}\text { Introduction to Artificial } \\
\text { Intelligence }\end{array}$ & $\begin{array}{l}\text { Supply Chain Management- } \\
\text { An Overview }\end{array}$ \\
\hline $\begin{array}{l}\text { Georg-August-University } \\
\text { Goettingen }\end{array}$ & $\begin{array}{l}\text { Information Processing in the } \\
\text { Service Industry }\end{array}$ & $\begin{array}{l}\text { IT support for Bank Lending } \\
\text { Processes }\end{array}$ \\
\hline $\begin{array}{l}\text { Leibniz University } \\
\text { Hannover }\end{array}$ & Mobile Business & $\begin{array}{l}\text { Introduction to } \\
\text { Mobile Business }\end{array}$ \\
\hline $\begin{array}{l}\text { Carl von Ossietzky } \\
\text { University Oldenburg }\end{array}$ & $\begin{array}{l}\text { Application Systems in } \\
\text { Industrial Enterprises }\end{array}$ & $\begin{array}{l}\text { Information Systems in } \\
\text { Manufacturing }\end{array}$ \\
\hline University of Osnabrueck & Electronic Commerce & $\begin{array}{l}\text { Applications in } \\
\text { Electronic Commerce }\end{array}$ \\
\hline
\end{tabular}

To describe the didactics of the different courses and modules from each partner is beyond the scope of this paper. The explanations in this paragraph only serve as a short summary. Those partners who already had an E-Learning course in operation had decided earlier on didactical concepts. In one case the course has the form of a Web-based Training (Conrad 2000), following constructivist approaches of situated learning (Cognition and Technology Group at Vanderbilt 1990, 1991; Collins, Braun \& Newman,1989; Collins, 1991). All partners who had to develop new courses for the purposes of the ATLANTIS project did it in the form of "Lectures on the fly" (Mertens, 2005): While delivering a course to the normal audience at their home university, the lecture was recorded in audio and video in parallel, and - in a back office process- synchronized with the presentation of the slides (usually using Powerpoint). A student who learns with such a recorded course can individually progress through the materials. The advantage of this kind of ELeaning arrangement is that is it comparably cost extensive (Hoppe, Klostermeier, Boll, Mertens, $\&$ Kleinefeld, 2007). Another partner developed a virtual collaborative learning (Balázs, 2005) course in which small groups of students have to work on case studies and to document their results in a wiki (Jonietz, 2005; Forte/Bruckman, 2007), strongly supported by moderated discussion boards. All E-learning courses have an additional service level agreement to give support over asynchronical communication tools like discussion threads or mail within 24 hours (week- 
ends excluded). The courses provide additional materials like readings in PDF-format or links to resources on the web, integrated in the central CMS. The courses are delivered in a blended learning mode in the sense of combining different activities and technologies for learning (for an overview of different definitions of blended learning see Graham, 2006).

\section{Costs and Benefits}

The ATLANTIS network is aimed at three main benefits:

- To overcome the problem of small subjects (see above): Each ATLANTIS Partner has to put one of his courses into the network and can, on the other hand, offer five additional courses from other locations to his students. However, this is a hypothetical value, because each partner will find in the portfolio of ATLANTIS courses which are already covered by existing courses at the importing location. Although avoiding overlaps in the selection has been considered when the subjects of courses to export into the network were agreed upon, this is to some degree inevitable. It is an indicator of redundancy in academic teaching when several universities are regarded from an overall perspective. The free choice of network courses which fit into the respective "home" program is further limited because courses are implicitly or explicitly designed with certain target groups in mind or they demand prerequisite knowledge (a course builds on knowledge attained in another course earlier in the program). An imported course might be so concentrated on technical issues that MIS students with a stronger emphasis on the applications of IT do not understand the contents easily. These caveats limit the potential of reusing elearning courses for expanded target groups significantly.

- In Hoppe and Packmohr (2007) the argument was brought forward that such a kind of inter-university cooperation in teaching can reveal benefits for the participating instructors in the form of improved teaching loads. A small example can illustrate this. A professor opens his course in Electronic Commerce to students at remote locations by placing the course into the ATLANTIS network. The blended learning scenario consists of selfguided studies of the electronic contents, organized in a Web-based Training, with integrated exercises. Additionally, the students have to work in small groups on given case studies, resulting in papers which are graded by the professor. Support and advises are available through discussion groups, e-mail and, twice in the semester via a videoconference, which is held between all locations where students are enrolled for the course. At the same time, this blended learning scenario is offered as a regular course to students who are studying at the faculty of this professor, i.e. his "own" students. The calculus is as follows: additional effort is caused by advising remote students and primarily by the additional grading (in addition to the written case studies there is usually a written exam). So, there is definitely more work to do. On the other hand she or he can take advantage of the network and import one (or more) additional course(s) from other locations. This offer can replace one of her or his courses. Given as granted that this cooperation in sustainable, the course portfolio of our professor can shrink by one course, meaning that a further focusing on the remaining subjects in teaching is possible. When the remaining subjects are in areas where the professor is especially strong in research, an increased unification of research and teaching might be a result. For the dispensable course there is no longer a need to actualize slides, materials and readings. All in all, the professor has one area less to cover in teaching and more students from remote locations in his remaining subjects. In an academic environment like Germany with heavy teaching load given by law, many professors will consider this exchange as beneficial. 
- After the Bologna reform, new Bachelor and Master Programs were created with more variety and a higher degree of multidisciplinarity in their composition. More modules and courses from other faculties have been integrated causing considerable overlap in students' timetables. Therefore, e-learning courses which can be studied every time, in the computer labs of the faculty, in the libraries or even at home give the students more flexibility. The formative evaluations which have been conducted for ATLANTIS support strongly that this benefit is perceived by the students.

Running the ATLANTIS network causes costs which have to be distinguished in those for regular operations and those for setting up the network. The technical platform and organizational rules were developed during the first two years, supported by grants from Lower Saxony. The whole amount of $€ 400.000$ (accumulated for two years and all partners) was spent almost completely for staff. The whole technical infrastructure was financed with approx. $€ 25.000$. This relatively little amount was possible because the project could use working results from former projects. At all participating locations services were already in place to support the parallel recording of lectures "on the fly". Every ATLANTIS University has one or more CMS running. So, the technical development was limited to set up another server with the central ATLANTIS LMS and to program an interface between this platform and the decentralized LMS at the respective universities to realize the single-sign-on functionality. Courses already existing in form of electronic media were enlarged and actualized. New courses were recorded, cut and amended with more materials in the first year. These activities were supported by project staff (a $50 \%$-contract over a period of two years for each participating partner and one 100\%-position for the coordinating partner).

To comply with the grant conditions it was necessary to show that the network can be operated sustainable after the end of the grant period. Today, rather little effort is necessary to keep the exchange running. This effort is borne from the regular staff of the chairs as part of the normal, contractual demanded teaching load. Due to well defined organizational processes (see below) the additional work to serve students from remote locations is little. At universities where it was possible to trade an own course against the import of a course from another university the total effect is positive.

\section{Organization}

At the beginning of the project structures and processes had to be defined. The organizational macro structure is the network itself. In a so called Memorandum of Understanding the following goals were fixed in 2007:

- Long term cooperation, in the first instance until 2012, prolongation intended.

- 200 students to subscribe to ATLANTIS courses per year, 2000 students to work with the ATLANTIS modules.

- Strengthening of the partners in research through more efficient teaching (cutting one course and replacing it by an imported ATLANTIS course).

- Diffusion of media technologies between the participation universities.

- Increasing flexibility of students who can attend E-Learning courses which are offered on a $24 / 7$ schedule.

Didactical goals contained to...

- improve the exemplification of abstract knowledge and processes by means of multimedia,

- improve the employability of students by means of blended learning scenarios, rooted in problem-based learning,

- use synergies in teaching in order to improve the quality of the electronic materials, 
- qualify students early in their Bachelor's programs for the use of electronic media.

Beyond that, the memorandum contained the commitment to the courses and modules from table 1 and organizational rules and responsibilities for each partner:

- Every partner is responsible for an ongoing periodic update of all contents the partner delivers.

- Questions from students via electronic communication have to be answered within 24 hours (weekend excluded).

- Waiving of courses required in local study programs against courses attended from ATLANTIS.

- Self dependant placement of e-learning courses and additional materials in the central LMS.

- Support and maintenance of the interface between local LMS and central LMS at the home university.

- Commitment to evaluate all ATLANTIS courses with a questionnaire every semester.

- All partners have to provide meta-data for each exported course for central directories listing all available electronic sources in Lower Saxony.

Finally, the memorandum defined the central process of examination and grading (Klostermeier, 2009) presented in figure 3. Although all Lower Saxon universities work under the same laws, organizational structures, responsibilities, time schedules, rules of grading, study program structures and more differ.

\begin{tabular}{|l|}
\hline - Conjoint finding of calendar dates for exam and registration for exam \\
- Test is sent to the course importer \\
- Students write the test at location of importer, supervisedby the importer \\
\hline - Solved tests are scanned into PDF-Format and sent to the course offerer \\
\hline - Test are graded by the course offerer \\
\hline - importer transmits grades to local office for tests and grades \\
\hline
\end{tabular}

Figure 3: Process of examination and grading 


\section{Lessons Learned}

\section{Curricular Integration is Difficult but Indispensable}

Under "curricular Integration" I understand the process of positioning an exported course into the study program of the importing partner. It has to be decided in which semester the course fits in. This is a relative complex task because since the Bologna reform, courses have been merged into modules. All courses of a module are to stand in a higher topically coherency. So, a lecture "Introduction to Electronic Commerce" would probably not fit in a module with two more courses about computer programming languages. Furthermore, modules have varying sizes. Before Bologna, the basic building blocks of study programs were the courses themselves - in form of lectures, seminars, exercises, etc. A prevalent size of a course in Germany was (and still is) 2 hours of contact time in a lecture hall over a semester of 15 weeks, completed by individual study effort for preparation and after work. For module sizes, there is no commonly accepted standard. In ATLANTIS an analysis of the study programs in MIS of the partners revealed a span ranging from 4 to 6 credits per course. Credits are translated into students' workload by multiplying a credit with 30 hours of student's work. So, 4 credits are equivalent to 120 working hours, 6 credits to 180 hours. Obviously, it makes a big difference in the scope of the course whether to deliver it as a 4 credit block or as a 6 credit block. It jeopardizes the principle of reusing the same contents and materials in one course for different importing locations. Furthermore, it means that the scope of the exams has to be adapted. The solution of this problem was to offer additional case studies and exercises which cover 2 more credits. As a result, the same courses are taken at different locations in two versions.

Another decision to make is to decide on the degree to which students are obliged to take an imported course. Courses may be "required", "optional" or "optionally required" the latter meaning that the student has to choose between several alternatives (like 2 courses out of 4 ). The ATLANTIS partner agreed to establish all imported courses in their home study programs as "optionally required" or "required". The partners wanted to make sure that the courses are taken from the very beginning of their offering to gain experiences in formative evaluations to improve the exchange. After the Bologna reform this is a requirement easily fulfilled because large parts of the installed Bachelor programs have only limited options, usually in higher semesters, to choose from. Any course placed in the first 2 or 3 semesters probably will be mandatory with no alternatives at hand.

Curricular integration is so important to the network because the individual benefit of reducing the portfolio of courses to deliver for an instructor only unfolds when he or she can trust in a sustainable exchange relationship. For a sustainable network you have to make sure that the exchange relationships have a long-term perspective. A course which cannot be installed into the official study program will at last be offered as an addition option to the already existing program. The willingness of students who have high course requirements to take additional courses out of intrinsic motivation is low.

\section{Heterogeneous Organizational Structures and Processes Cause High Costs for Coordination}

Different structures in study programs have already been stated as a problem in shaping the ATLANTIS courses. There are more inconsistencies in organizational rules and processes concerning study times, dates of exams and grading.

Although all partners in ATLANTIS are situated in the same Bundesland in Germany, study times vary considerably: semesters start within a variation of 2 weeks and accordingly they end one or two weeks later. You would not expect this to be a problem for E-Learning courses offered 
on a $24 / 7$ schedule. Anyhow, the problem occurs that exams have to be placed at the end of the lecture periods. All participating universities have fixed periods of examination (usually 2-3 weeks), following the end of lecture period. A logical requirement for examinations and tests in ATLANTIS is that all students who take the same course from ATLANTIS should write the same test, disregarded from the location where they are enrolled. This demands that all tests which are in fact written at different places are completed at the very same time. Otherwise students would have the chance to quickly communicate test questions to their fellow students at other locations who would write the tests later. And the question would arise if this examination has been fair to every testee.

Some partners have study rules which exactly state allowed forms of exams. For example a written test or oral exam might be permitted, whereas a case study might be prohibited or only acceptable in predefined modules or phases of a study program. Again, against the background of equal tests for all ATLANTIS students this creates a problem and might lead to the exclusion of certain forms of tests for all students involved. To change such a study regime is only a hypothetical option with an open result: academic ruling at public German universities demands that such changes are decided on several hierarchical levels of the institution: at least at levels of the faculty, the university and often- despite all initiatives to give more autonomy to universities - the federal ministries for education and research. Such a process might take between 9 and 15 months and it will cause considerable coordination costs because after a successful change you get different cohorts of students (one studying under old conditions, one studying after new ones), which you have to treat differently.

\section{Incentives for Instructors to Participate in Exchange Relationships Are Low}

One of the preconditions for professors as chair holders and primary decision maker to engage in such an exchange network is that they consider the cooperation as beneficial. During an externally financed project this is not a question. The research project and the grant are indicators of successful research. But after the end of the project, when the projects changes to normal operation, these incentives fade. As described above, there is definitely more coordination effort necessary to cross borders between universities. And there is more advising and grading due to the additional students. Only if - and it is a big "if" - the cooperation is stable enough to last for a long period, a professor might take the chance to give up one of his elaborated courses (probably with materials, slides, exercises, sample solutions, etc.) and the actual knowledge to deliver the course. At present, it is not ruled by law that courses which are opened to students from other universities "count" for the teaching obligations of a professor. She or he might end up just with more work, without any compensation. Individual arrangements at every university are possible but painful and the result is open.

Furthermore, there are no direct financial payments for additional courses from the faculties. Additional teaching assignments for courses already exceeding high teaching duties are paid with ridiculous little money. In the faculty of the author an additional course has to be authorized in a multilevel process. With a separate written explanation "why this course is so demanding" a course might be paid with $€ 1500$.

Finally, there is no institutional financial support for such networks. Usually partners do not get money to operate the network. At some locations there are chances to get temporally internal university money for innovative teaching. This money is restricted to activities at the respective location where it is given. So, it doesn't help too much when at same time other partner are not that lucky. A sustainable funding would need a positive decision from all participation university presidents to support the network and demand a signed cooperation contract - a rather unlikely event in these dynamic times. The alternative is to run the network with existing staff and capaci- 
ties taken from the chairs involved. That is the present solution, and it kind of hurts that it lacks a reward for the gains in flexibility for the students and for the broadening of study offers.

Between faculties at the same university in Germany there is usually a controlling system, counting students who are enrolled for a study program offered from one faculty, but taking some courses from other faculties. This leads to financial compensation, for example in the area of study fees. An analogous system could be installed for exchange relationships between different universities. But at the moment this kind of exchange relationship is too rare and still too experimental to justify such an endeavor.

\section{Conclusions}

Educational networks in academic teaching can be a valuable resource. Interestingly, the main challenges are not technically or didactically in nature. Far more important are organizational and economical issues. Due to little standardization in German academic teaching processes and the complexity in study programs, most notably after the Bologna reform, the exchange of educational offerings in teaching between universities is hindered and still causes high coordination costs. The $21^{\text {st }}$ century has started as a time of developing knowledge societies, supported by a fast evolving web. The question might be posed how much longer a weekly financed public university system like in Germany can afford to fund redundant capacities in teaching, even at regionally close locations.

The experiences reported in this paper and the conclusions drawn are somewhat dependent upon circumstances and rules of the German public university system. They cannot be directly transferred to other countries and continents.

\section{References}

Balázs, I. E. (2005). Konzeption von Virtual Collaborative Learning Projekten: Ein Vorgehen zur systematischen Entscheidungsfindung [Conception of virtual collaborative learning projects: An approach to systematic decision making]. Unpublished doctoral dissertation, Technische Universitaet Dresden. Retrieved December 15, 2009, from http://www.qucosa.de/fileadmin /data/qucosa/documents/1267/1111134624957-2129.pdf

Bohl, O., Frankfurth, A., Schellhase, J. \&, Winand, U. (2007). Winfoline - Effekte eines Bildungsnetzwerk [Winfoline - Effects of an educational network]. In Breitner, M., Bruns, B. \& Lehner, F. (Eds.), Neue Trends im E-Learning: Aspekte der Betriebswirtschaftslehre und Informatik [New trends in e-learning: Aspects of business studies and information technology] (pp 17-28). Heidelberg: Physica-Verlag.

Coates, H., James, R. \& Baldwin, G. (2005). A critical examination of the effects of learning management systems on university. Tertiary Education and Management, 11(1), 19-36.

Cognition and Technology Group at Vanderbilt. (1990). Anchored instruction and its relationship to situated cognition. Educational Researcher, 19(6), 2-10.

Cognition and Technology Group at Vanderbilt. (1993). Anchored instruction and situated cognition revisited. Educational Technology, 33, 52-70.

Conrad, K. A. (200). Instructional design for web-based training. Amherst, MA: HRD Press.

Collins, A. (1991). Cognitive apprenticeship and instructional technology. In Idol, L. \& Jones, B. F. (Eds.), Educational values and cognitive instruction: Implications for reform (pp. 121-138). Hillsdale, NJ: Lawrence Erlbaum Associates.

Collins, A., Braun, J. S. \& Newman, S. E. (1989). Cognitive apprenticeship: Teaching the crafts of reading, writing and mathematics. In L. B. Resnick (Ed.), Knowing, learning and instruction: Essays in honour of Robert Glaser (pp.453-494). Hillsdale, NJ: Lawrence Erlbaum Associates. 
Crosier, D., Purser, L. \& Smidt, H. (2007). Trend V: Universities shaping the European higher education area. EUA report. Retrieved December 15, 2009 from http://www.eua.be/fileadmin/user_upload/files/Publications/EUA_Trends_V for_web.pdf

Gieseking, M. \& Vornberger, O. (2008). Media2mult - A wiki-based authoring tool for collaborative development of multimedial documents. In M. B. Nubes \& M. McPherson (Eds.), Proceedings of the IADIS International Conference e-Learning in Amsterdam 2008.

Graham, C. R. (2006). Blended learning systems: Definition, current trend, and future directions. In C. J. Bonk \& C. R. Graham (Eds.), The handbook of blended learning: Global perspectives, local designs (pp. 3-21). San Francisco, CA: Jossey-Bass/Pfeiffer.

Hagenhoff, S. (2000). WINFOLine - ein Beispiel fuer eine kooperative internetbasierte Lernwelt [WINFOLine - An example for the cooperative webbased learning world]. ZfB Ergaenzungsheft Hochschuldidaktik (3), 205-218.

Hoppe, U., Klostermeier, F., Boll, S., Mertens, R. \& Kleinefeld, N. (2007). Wirtschaftlichkeit von Geschaeftsmodellen fuer universitaere Lehrkooperationen: eine Fallstudie [The economy of business models in teaching cooperations at universities: a case study]. Zeitschrift fuer E-Learning, 2(3), 29-40.

Hoppe, U. \& Packmohr, S. (2007). Barter als Geschaeftsmodell fuer den interuniversitaeren Tausch von Lehrangeboten [Barter as a business model for the inter-university exchange of courses]. In Breitner, M. H., Bruns, B. \& Lehner, F. (Eds.), Neue Trends im E-Learning: Aspekte der Betriebswirtschaftlehre und Informatik [New trends in e-learning: Aspects of business studies and information technology] (pp. 227-244). Heidelberg: Physica-Verlag.

Klostermeier, F. (2009): Projektmanagement im ELAN III-Projekt ATLANTIS [Projectmanagement in the ELAN III-Project ATLANTIS]. In Appelrath, H-J. \& Schulze, L. (Eds.): Auf dem Weg zu exzellentem E-Learning. Vernetzung und Kooperation der Hochschullehre in Niedersachsen [On the way towards excellent e-learning. Networking and cooperation of the tertiary apprenticeship in Lower Saxony] (pp. 174-183). Muenster, Westf: Waxmann.

Reichert, S. \& Tauch, C. (2005). Trends IV: European universities implementing Bologna. EUA Report. Retrieved December 15, 2009 from http://www.eua.be/eua/jsp/en/upload/TrendsIV_FINAL.1117012084971.pdf

\section{Biography}

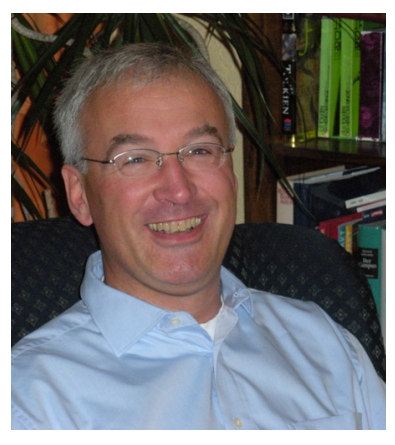

Uwe Hoppe is a tenured Professor in the Information Systems and Management department at the University of Osnabrueck, Germany. He holds a doctorate from University of Goettingen, where he also received his Diploma in Business Administration. His principal research areas are the impacts of Information Technologies on organizational structures and processes and the development and application of eLearning technologies like Campus Management Systems and Blended-Learning Environments. Currently, he is director of the MIS Institute at the College of Business Administration and Economics at University of Osnabrueck. 